Hydrology and Earth System Sciences, 6(3), 363-374 (2002) C EGS

\title{
Spatial variability of throughfall water and chemistry and forest floor water content in a Douglas fir forest stand
}

\author{
K.J. Raat ${ }^{1}$, G.P.J. Draaijers ${ }^{2}$, M.G. Schaap ${ }^{3}$, A. Tietema ${ }^{1}$ and J.M. Verstraten ${ }^{1}$ \\ ${ }^{1}$ Centre for Geo-Ecological Research (ICG), Institute for Biodiversity and Ecosystem Dynamics (IBED) - Physical Geography, Universiteit van Amsterdam, Nieuwe \\ Achtergracht 166, NL-1018WV Amsterdam, The Netherlands \\ ${ }^{2}$ TNO Institute of Environmental Sciences, Energy Research and Process Innovation (TNO-MEP), P.O. Box 342, NL-7300 AH Apeldoorn, The Netherlands \\ ${ }^{3}$ George E. Brown Jr. Salinity Laboratory, USDA-ARS, 450 W. Big Springs Road, Riverside, CA 92507, USA
}

Email for corresponding author: k.raat@science.uva.nl

\begin{abstract}
This study focuses on spatial variability of throughfall water and chemistry and forest floor water content within a Douglas fir (Pseudotsuga menziesii, Franco L.) forest plot. Spatial patterns of water and chemistry $\left(\mathrm{NH}_{4}^{+}, \mathrm{NO}_{3}^{-}, \mathrm{SO}_{4}{ }^{2-}, \mathrm{Cl}^{-}, \mathrm{Mg}^{2+}, \mathrm{Ca}^{2+}, \mathrm{Na}^{+}\right.$and $\left.\mathrm{K}^{+}\right)$were compared and tested for stability over time. The spatial coefficient of variation (CV) was between 18 and $26 \%$ for amounts of throughfall water and ions, and $17 \%$ for forest floor water content. Concentrations and amounts of all ions were correlated significantly. Ion concentrations were negatively correlated with throughfall water amounts, but, except for $\mathrm{NH}_{4}^{+}$, there was no such relation between throughfall water and ion amounts. Spatial patterns of throughfall water fluxes and forest floor water contents were consistent over time; patterns of ion fluxes were somewhat less stable. Because of the spatial variability of forest floor thickness and drainage, it was not possible to relate patterns in throughfall water directly to patterns in water content. The spatial variability of throughfall nitrogen and forest floor water contents can cause significant variability in $\mathrm{NO}_{3}^{-}$production within the plot studied.
\end{abstract}

Keywords: nutrient throughfall, forest floor water, spatial variability, time-stability, nitrogen

\section{Introduction}

Increased atmospheric deposition of nitrogen and sulphur has led to problems in forest ecosystems, such as soil acidification, unbalanced nutrition of trees and high leakage of nitrate towards groundwater (Aber et al., 1989; Magill et al., 1997; Van Breemen et al., 1982). These problems have initiated intensive scientific research in the field of nitrogen cycling. Research has focused on field budget studies (Tietema and Verstraten, 1992), field manipulation studies (Wright et al., 1995), $\mathrm{N}$ modelling (Cosby et al., 1997; Whitehead et al., 1998) and laboratory experiments (Tietema and Van Dam, 1996).

Generally, field studies are applied at a plot scale, and field experiments at a number of points within a field plot. Such studies have not been designed to sample the spatial heterogeneity that normally exists in a plot, because the questions driving the research required only a site average with preferably a small standard deviation (Vogt et al., 1995). Although this low-resolution research is necessary, it does overlook a rich abundance of information found at a higher resolution. For example, individual plants may affect or respond to their environment at smaller scales. This is shown, for example, by Bouten et al. (1992) who found spatial patterns of root water uptake to be related to throughfall patterns around trees, especially in dry months. Ignoring spatial variability not only results in information being overlooked, it can also have considerable consequences for the reliability of the models (Harden and Joergensen, 2000; Parkin, 1993) and thus for the validity of the concepts derived from these models.

The temporal resolution of nitrogen research is generally in the order of weeks or months. A process like denitrification, however, has a very high temporal variability (Martin et al., 1999). Short-term (hours, days) changes in, for example, soil water contents can have large effects on microbial transformations (Pulleman and Tietema, 1999). Recently, short-term research, especially on so-called priming effects, has received more attention (Kuzyakov et al., 2000).

Throughfall is an important pathway of nutrients to the 
forest floor. Forest floor water is important for the water and nutrient supply to plants, and forest floor water contents control several microbiological processes. Both throughfall water and ion fluxes and forest floor water contents have a high spatial and temporal variability. A number of studies has addressed the spatial variability of throughfall (Kimmins, 1973; Robson et al., 1994) and the distribution of throughfall, both ions and water, has been related to the distance from a tree stem (Beier et al., 1993; Pedersen, 1992; Whelan et al., 1998). Generally, for coniferous forests, concentrations and fluxes of ions decrease and water fluxes increase with distance from the tree stem. Hansen et al. (1994) have addressed the short-term temporal variability of throughfall by analysing the changes in throughfall chemical composition during two rain showers in The Netherlands. They show that a significant portion of the yearly nitrogen throughfall can be added to the forest floor during a single shower. Schaap et al. (1997a) have shown that although forest floor water contents show high spatial variabilities within a field plot, their temporal dynamics are very similar. Schaap and co-workers also showed that the observed spatial patterns in forest floor water content are consistent over time. Despite its importance, research done on forest floor water dynamics and patterns is still scarce.

In this study, throughfall water and chemistry and forest floor water content data for a Douglas fir forest subject to high levels of atmospheric $\mathrm{N}$ deposition, were analysed for small-scale, within-plot, spatial patterns. Throughfall and soil water data were collected by Draaijers et al. (1998) and Schaap et al. (1997a), respectively. Time-stability of observed throughfall patterns and the correlation between patterns of different throughfall ions and throughfall water were assessed. In addition, the link between spatial patterns in throughfall water and patterns in forest floor water was examined by analysing forest floor water contents during six rain showers. For two of these showers, forest floor water temporal dynamics were compared with dynamics in nitrogen throughfall (throughfall data of Hansen et al., 1994). In this paper, the results of these analyses are presented and the implications of the findings for $\mathrm{N}$ modelling and $\mathrm{N}$ process research are discussed.

\section{Materials and methods}

\section{SITE DESCRIPTION}

The Speuld research site is a 2.5 ha Douglas fir (Pseudotsuga menziesii, Franco L.) forest stand, located in the centre of The Netherlands. At the time of measurement (1992-1993), trees were 31 years old and 16 to $21 \mathrm{~m}$ high. Tree density varied between 785 and 1250 trees ha ${ }^{-1}$. The canopy was well-closed with a one-sided leaf area index (LAI) ranging from 9 in early spring to $12 \mathrm{~m}^{2} \mathrm{~m}^{-2}$ at the end of summer. There was no understorey vegetation. The forest floor had a thickness of $5.9 \mathrm{~cm}$ (Schaap et al., 1997a), and was classified as a Moder humus form (Green et al., 1993). The average forest floor water storage in winter was approximately $10 \mathrm{~mm}$ (Tiktak and Bouten, 1990). The soil is a well-drained, acid, sandy Haplic Podzol (FAO, 1988), formed from ice-pushed pre-glacial deposits of the river Rhine. The groundwater level was at $40 \mathrm{~m}$ depth throughout the year. Average precipitation was $834 \mathrm{~mm} \mathrm{yr}^{-1}$, while mean potential evapotranspiration was $712 \mathrm{~mm} \mathrm{yr}^{-1}$ (Tiktak and Bouten, 1994). Nitrogen deposition in throughfall amounted to $42 \mathrm{~kg}-\mathrm{N}$ ha $\mathrm{yr}^{-1}$, mainly in the form of $\mathrm{NH}_{4}^{+}$. Nitrogen

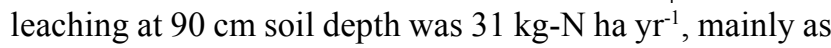
$\mathrm{NO}_{3}^{-}$. Nitrogen transformations occurred mainly in the forest floor (Tietema et al., 1993).

The climate in the region is temperate-humid. Precipitation averages 800 to $835 \mathrm{~mm} \mathrm{yr}^{-1}$, which is spread evenly over the year. The coldest month is January with an average temperature of $1.6^{\circ} \mathrm{C}$ and the warmest month is August, averaging $16.6^{\circ} \mathrm{C}$.

\section{THROUGHFALL MEASUREMENTS}

Throughfall was collected for nine periods between October 1992 and June 1993 (Table 1) with 25 funnels each with a collection area of $320 \mathrm{~cm}^{2}$. After collection, samples were filtered $(0.45 \mu \mathrm{m})$ and stored dark and cool $\left(5^{\circ} \mathrm{C}\right)$. Ion concentrations were measured within one week of sampling. Samples were analysed by colorimetry on a Skalar autoanalyzer for $\mathrm{NH}_{4}^{+}, \mathrm{NO}_{3}^{-}, \mathrm{SO}_{4}^{2-}, \mathrm{Cl}^{-}, \mathrm{Mg}^{2+}$, and $\mathrm{Ca}^{2+}$. Concentrations of $\mathrm{Na}^{+}$and $\mathrm{K}^{+}$were determined by flame photometry. Throughfall water amounts were always

Table 1. Throughfall collection periods and average amount of throughfall water collected in those periods $(\mathrm{n}=25)$.

\begin{tabular}{llrr}
\hline Period & Date & $\begin{array}{l}\text { Days } \\
\text { in period }\end{array}$ & $\begin{array}{l}\text { Average } \\
\text { through- } \\
\text { fall (mm) }\end{array}$ \\
\hline 1 & 1 Oct. - 7 Oct., 1992 & 6 & 8.8 \\
2 & 7 Oct. - 20 Oct., 1992 & 13 & 21.9 \\
3 & 20 Oct. - 2 Nov., 1992 & 13 & 3.9 \\
4 & 2 Nov. - 4 Nov., 1992 & 2 & 7.5 \\
5 & 4 Nov. - 17 Nov., 1992 & 13 & 31.2 \\
6 & 8 Dec. - 15 Dec., 1992 & 7 & 18.5 \\
7 & 12 Apr. - 20 Apr., 1993 & 8 & 18.9 \\
8 & 20 Apr. - 10 May., 1993 & 20 & 25.0 \\
9 & 10 May - 3 June, 1993 & 24 & 25.0 \\
\hline
\end{tabular}


determined, but unfortunately, some $2.5 \%$ of the chemical throughfall data were missing. In order to calculate throughfall ion fluxes for every individual throughfall funnel over the total 107 collection days, these missing concentration values were interpolated (Draaijers et al., 1998). Stemflow was not taken into account in this study; the stemflow ion flux in this forest was estimated to be $6 \%$ of the throughfall ion flux (Van Leeuwen et al., 1994).

\section{FOREST FLOOR WATER CONTENT MEASUREMENTS}

Forest floor water contents were measured six to eight times a day with an automated TDR system (Heimovaara and Bouten, 1990). Special interest was taken in the water content dynamics during six larger showers in the period between April 5 and July 6, 1993. TDR sensors, $35 \mathrm{~cm}$ in length, were installed horizontally about $10 \mathrm{~cm}$ apart in parallel in the forest floor. Five clusters of 6 sensors were used; the largest distance between the clusters was $10 \mathrm{~m}$. Sensor depth ranged from 1.5 to $7.6 \mathrm{~cm}$ from the surface; the average depth was $3.4 \mathrm{~cm}$. In this part of the forest stand, the thickness of the forest floor varied from 3.3 to $9.6 \mathrm{~cm}$, with an average of $5.9 \mathrm{~cm}\left(6.0 \mathrm{~kg} \mathrm{~m}^{-2}\right)$. Reference is made to Schaap et al. $(1997 \mathrm{a}, \mathrm{b})$ for a more detailed description of the forest floor water content measurements and TDR calibration in forest floor media.

\section{TIME STABILITY OF SPATIAL PATTERNS}

Two techniques were applied to investigate the temporal stability of observed spatial patterns. The first technique is the 'time stability' method described by Vachaud et al. (1985). They and others (Gómez-Plaza et al., 2000) have applied this method to soil water storage data, but it may equally be applied to throughfall or other spatial data. For $m$ periods and $n$ locations, the method calculates the temporal average $\left(\bar{\delta}_{j}\right)$ and standard deviation of the relative difference $\delta_{t, j}$ of a variable $S_{t, j}(t=$ time, $j=$ location $)$ :

$$
\bar{\delta}_{j}=\frac{1}{m} \sum_{t=1}^{m} \delta_{t, j}
$$

where

$$
\delta_{t, j}=\frac{S_{t, j}-\bar{S}_{t}}{\bar{S}_{t}}
$$

and

$$
\bar{S}_{t}=\frac{1}{n} \sum_{j=1}^{n} S_{t, j}
$$

When ranked from smallest to largest and plotted, the $\bar{\delta}_{j}$ gives a good visual representation of the relative deviation of a variable from the plot mean at the various locations $j$ within a plot (see, for example, Fig. 2). Averaged over time, locations at the left side of such a graph $\left(\bar{\delta}_{j}<0\right)$ are below the time-average plot mean and locations at the right side $\left(\bar{\delta}_{j}>0\right)$ are above average. This method was applied to the throughfall data for $t=9$ periods and $j=25$ locations (funnels).

The second technique, also applied by Vachaud et al. (1985), is the non-parametric Spearman's test. Let $R_{t, j}$ be the rank of the variable $S_{t, j}$ observed at location $j$ at time $t$ and $R_{t^{\prime}, j}$ the rank of the same variable at the same location, but on date $t^{\prime}$. The Spearman rank correlation coefficient is then calculated by

$$
r_{s}=1-\frac{6 \sum_{i=1}^{n}\left(R_{t, j}-R_{\mathrm{t}^{\mathrm{t}}, \mathrm{j}}\right)^{2}}{n\left(n^{2}-1\right)}
$$

where $n$ is the number of observations. A value of $r_{s}=1$ corresponds to identity of rank for any site, or perfect timestability between dates $t$ and $t^{\prime}$. The closer $r_{s}$ is to 1 , the more stable in time the spatial pattern will be.

\section{Results and discussion}

\section{SPATIAL PATTERNS OF THROUGHFALL}

The total amounts of throughfall, both in terms of ions and water, were summed over the 9 periods (Table 2). The ratio of the highest to the lowest catch in a funnel was 2.2, 2.8, 2.6 and 2.8 for water, $\mathrm{NH}_{4}^{+}, \mathrm{NO}_{3}{ }^{-}$and total inorganic-N, respectively. The coefficient of variation (CV) for these variables was 21, 26, 19 and 24\%. These ratios and CVs show a significant spread in throughfall ion and water input within the field plot. For water, however, the ratio and CV are considerably lower than the 3.5 and $30 \%$ recorded by Bouten et al. (1992) for the same forest over a 18 months period in 1988-1990. The funnels they used had a slightly larger collection surface than those used here (480 v. 320 $\mathrm{cm}^{2}$ ), which should generally result in a smaller rather than a larger CV. There are two possible explanations for the lower CV in the present study. Firstly, Bouten et al. (1992) conducted their measurements at a different location within the forest stand. Tree density varies between 785 and 1250 trees $\mathrm{ha}^{-1}$ within the forest stand; a higher tree density generally results in a lower CV. Secondly, the periods in which the present study was undertaken were characterised by relatively high amounts of precipitation. Throughfall shows less spatial variation in periods with high rain intensities (Bouten et al., 1992).

For all but $\mathrm{NH}_{4}^{+}, \mathrm{CVs}$ are smaller than those reported by Beier et al. (1993), Seiler and Matzner (1995) and Whelan 
Table 2. Mean, standard deviation, coeffient of variation, minimum, maximum and maximum/ minimum ratio of water and ion throughfall inputs for 25 funnels summed over nine periods (covering a total of 107 days). Water amounts in $\mathrm{mm}$, ion amounts in $\mathrm{mol} \mathrm{ha}^{-1}$; funnel number in brackets.

\begin{tabular}{lcccccc}
\hline & mean & std.dev. & $C V(\%)$ & minimum & maximum & max./min. ratio \\
\hline water & 161 & 33 & 21 & $109(22)$ & $232(4)$ & 2.13 \\
& & & & & & \\
& & & & & & \\
$\mathrm{NH}_{4}^{+}$ & 727 & 190 & 26 & $455(19)$ & $1290(15)$ & 2.84 \\
$\mathrm{NO}_{3}^{-}$ & 278 & 54 & 19 & $164(19)$ & $422(15)$ & 2.57 \\
$\mathrm{NH}_{4}^{+}+\mathrm{NO}_{3}^{-}$ & 1005 & 240 & 24 & $619(19)$ & $1712(15)$ & 2.77 \\
& & & & & & \\
$\mathrm{Cl}^{-}$ & 278 & 61 & 22 & $185(7)$ & $451(15)$ & 2.43 \\
$\mathrm{SO}_{4}^{2-}$ & 306 & 79 & 26 & $195(19)$ & $516(15)$ & 2.64 \\
$\mathrm{Na}^{+}$ & 233 & 60 & 26 & $152(7)$ & $397(15)$ & 2.61 \\
$\mathrm{~K}^{+}$ & 137 & 24 & 18 & $97.9(22)$ & $185(10)$ & 1.89 \\
$\mathrm{Mg}^{2+}$ & 42.2 & 7.9 & 19 & $28.0(7)$ & $60.2(15)$ & 2.15 \\
$\mathrm{Ca}^{2+}$ & 48.5 & 10 & 20 & $31.4(19)$ & $66.6(15)$ & 2.12 \\
\hline
\end{tabular}

Table 3. (Spatial) coefficients of variation (CV, \%) of throughfall in this and four other studies in coniferous forests: Pedersen (1992), Beier et al. (1993), Seiler and Matzner (1995) and Whelan et al. (1998). CVs of ions in Pedersen (1992) and Seiler and Matzner (1995) refer to time-average concentrations; all other studies refer to amounts. CVs in Whelan et al. (1998) are for individual collection periods of 9 to 17 days length. CVs in Pedersen (1992) refer to three even-aged Sitka spruce forests.

\begin{tabular}{|c|c|c|c|c|c|}
\hline & $\begin{array}{l}\text { present study } \\
(n=25)\end{array}$ & $\begin{array}{l}\text { Pedersen } \\
(n=30)\end{array}$ & $\begin{array}{l}\text { Beier et al. } \\
(n=20)\end{array}$ & $\begin{array}{l}\text { Seiler and } \\
\text { Matzner } \\
(n=100)\end{array}$ & $\begin{array}{l}\text { Whelan et al. } \\
(n=39)\end{array}$ \\
\hline forest type & Douglas fir & Sitka spruce & Norway spruce & Norway spruce & Norway spruce \\
\hline forest age [yr] & 31 & 30 & 40 & 140 & 52 \\
\hline coll. area $\left[\mathrm{cm}^{2}\right]$ & 320 & 121 & 178 & 106 & 178 \\
\hline coll. time $[\mathrm{d}]$ & 107 & 365 & 365 & $\sim 184$ & $9-17$ \\
\hline water & 21 & $21-23$ & & 3 & $7-16$ \\
\hline $\mathrm{NH}_{4}^{+}$ & 26 & $29-53$ & 44 & 24 & $38-175$ \\
\hline $\mathrm{NO}_{3}^{-}$ & 19 & $26-37$ & 39 & 29 & $23-62$ \\
\hline $\mathrm{Cl}^{-}$ & 22 & $33-47$ & 42 & 61 & $18-57$ \\
\hline $\mathrm{SO}_{4}^{2-}$ & 26 & $28-47$ & 41 & 38 & $23-44$ \\
\hline $\mathrm{Na}^{+}$ & 26 & $33-47$ & 45 & 42 & \\
\hline $\mathrm{K}^{+}$ & 18 & $25-34$ & 32 & 30 & $11-43$ \\
\hline $\mathrm{Mg}^{2+}$ & 19 & $34-47$ & 44 & 34 & \\
\hline $\mathrm{Ca}^{2+}$ & 20 & $31-44$ & 44 & 33 & \\
\hline
\end{tabular}


et al. (1998) in Norway spruce stands, and Pedersen (1992) in three Sitka spruce stands (Table 3). The funnel collection area used in this study is larger than the collection area used in these other studies, which could explain the smaller CVs in this study. Seiler and Matzner (1995) attributed the small $\mathrm{CV}$ for $\mathrm{NH}_{4}^{+}$in their study to foliar uptake of $\mathrm{NH}_{4}^{+}$(and $\mathrm{NO}_{3}^{-}$), counteracting the enlarging effect that dry deposition generally has on ion throughfall flux spatial variability. At Speuld, there is some retention of $\mathrm{NH}_{\mathrm{x}}$ and $\mathrm{NO}_{\mathrm{x}}$ in the canopy (Draaijers et al., 1997), but this retention is insufficiently large to counteract the relatively high $\mathrm{NH}_{x}$ and $\mathrm{NO}_{\mathrm{x}}$ deposition in this forest. Consequently, these CVs for throughfall $\mathrm{NH}_{4}^{+}$and $\mathrm{NO}_{3}^{-}$will not be influenced significantly by foliar uptake.

Time-average ion concentrations of funnels, being the total ion input during the collection period (107 days) divided by the total amount of throughfall water, were positively correlated with one another and negatively correlated with the amount of throughfall water (Table 4 and Fig. 1). The strong correlations between all ions occur, even though

Table 4. Pearson correlation coefficients for throughfall water amounts and time-average concentrations. Total collection time 107 days; $\mathrm{n}=25,{ }^{* *} \mathrm{p}=0.01$ (two-tailed).

\begin{tabular}{|c|c|c|c|c|c|c|c|c|c|}
\hline $\begin{array}{l}\text { water } \\
1\end{array}$ & $\begin{array}{l}\mathrm{NH}_{4}^{+} \\
-.71^{* *} \\
1\end{array}$ & $\begin{array}{l}\mathrm{NO}_{3}^{-} \\
-.74^{-* *} \\
.97 * * \\
1\end{array}$ & $\begin{array}{l}\mathrm{Cl}^{-} \\
-.58 * * \\
.91 * * \\
.89 * * \\
1\end{array}$ & $\begin{array}{l}\mathrm{SO}_{4}^{2-} \\
-.68^{* *} \\
.97 * * \\
.94 * * \\
.95 * * \\
1\end{array}$ & $\begin{array}{l}\mathrm{Na}^{+} \\
-.61^{* *} \\
.96^{* *} \\
.93^{* *} \\
.98^{* *} \\
.98^{* *} \\
1\end{array}$ & $\begin{array}{l}\mathrm{K}^{+} \\
-.69^{* *} \\
.83^{* *} \\
.85^{* *} \\
.78^{* *} \\
.84^{* *} \\
.81^{* *} \\
1\end{array}$ & $\begin{array}{l}\mathrm{Mg}^{2+} \\
-.65 * * \\
.91 * * \\
.90^{* *} \\
.97 * * \\
.97 * * \\
.96 * * \\
.80 * * \\
1\end{array}$ & $\begin{array}{l}\mathrm{Ca}^{2+} \\
-.64^{* *} \\
.85^{* *} \\
.84^{* *} \\
.91^{* *} \\
.93^{* *} \\
.89^{* *} \\
.78^{* *} \\
.97^{* *} \\
1\end{array}$ & $\begin{array}{l}\text { water } \\
\mathrm{NH}_{4}^{+} \\
\mathrm{NO}_{3}^{-} \\
\mathrm{Cl}^{-} \\
\mathrm{SO}_{4}^{2-} \\
\mathrm{Na}^{2} \\
\mathrm{~K}^{+} \\
\mathrm{Mg}^{2+} \\
\mathrm{Ca}^{2+}\end{array}$ \\
\hline
\end{tabular}

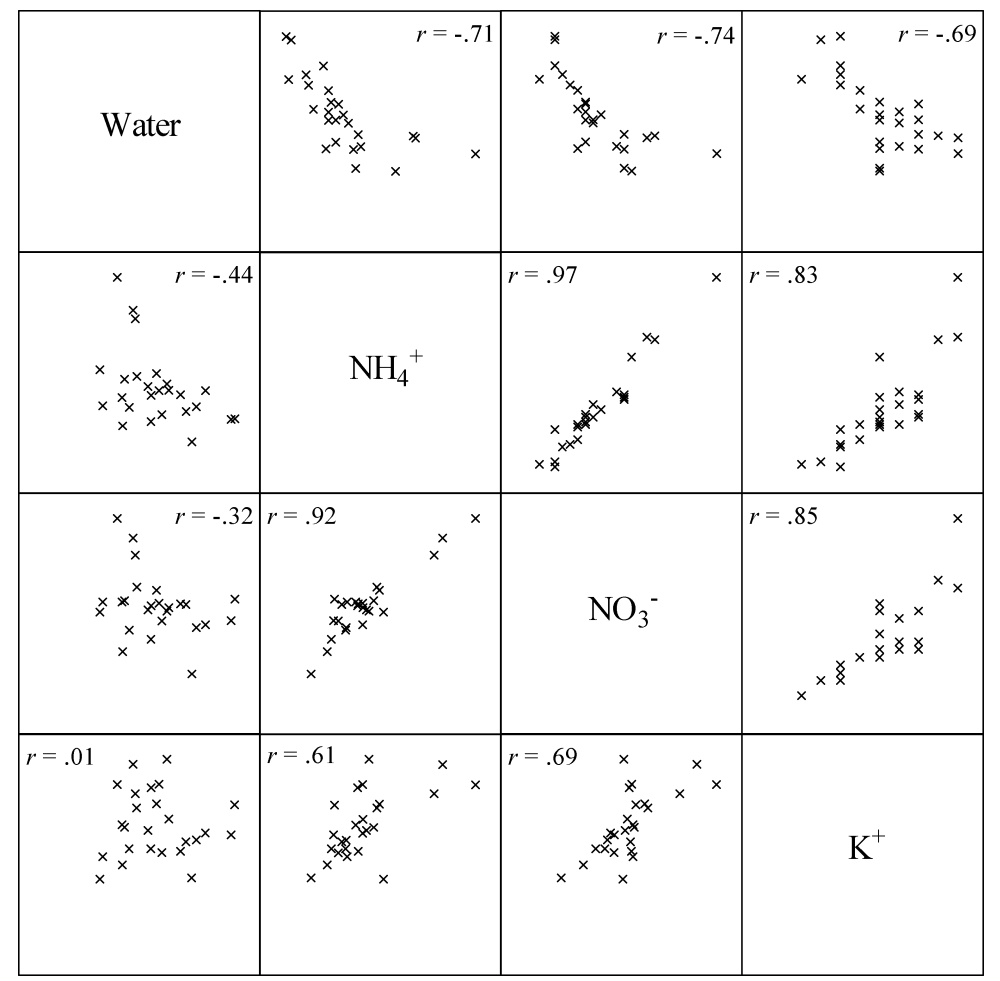

Fig. 1. Scatter plots of throughfall water amounts and time-average concentrations, and time-average concentrations mutually (upper-right) and of throughfall water amounts and ion amounts, and throughfall ion amounts mutually (lower-left). Spearman rank correlations (r) are given; see Table 4 and 5 for significance of correlations. 
Table 5. Pearson correlation coefficients for throughfall water and ion amounts. Total collection time 107 days; $\mathrm{n}=25, * p=0.05, * * p=0.01$ (two-tailed).

\begin{tabular}{llllllllll}
\hline water & $\mathrm{NH}_{4}^{+}$ & $\mathrm{NO}_{3}^{-}$ & $\mathrm{Cl}$ & $\mathrm{SO}_{4}^{2-}$ & $\mathrm{Na}^{+}$ & $\mathrm{K}^{+}$ & $\mathrm{Mg}^{2+}$ & $\mathrm{Ca}^{2+}$ & \\
1 & $-.44^{*}$ & -.32 & -.06 & -.39 & -.20 & .01 & -.12 & -.16 & water \\
& 1 & $.92^{* *}$ & $.84^{* *}$ & $.98^{* *}$ & $.91^{* *}$ & $.61^{* *}$ & $.83^{* *}$ & $.77^{* *}$ & $\mathrm{NH}_{4}^{+}$ \\
& 1 & $.81^{* *}$ & $.92^{* *}$ & $.88^{* *}$ & $.69^{* *}$ & $.84^{* *}$ & $.77^{* *}$ & $\mathrm{NO}_{3}^{-}$ \\
& & & 1 & $.89^{* *}$ & $.97^{* *}$ & $.66^{* *}$ & $.95^{* *}$ & $.86^{* *}$ & $\mathrm{Cl}^{-}$ \\
& & & $1^{* *}$ & $.95^{* *}$ & $.63^{* *}$ & $.90^{* *}$ & $.86^{* *}$ & $\mathrm{SO}_{4}^{2-}$ \\
& & & & $1^{* *}$ & $.67^{* *}$ & $.95^{* *}$ & $.86^{* *}$ & $\mathrm{Na}^{+}$ \\
& & & & & 1 & $.65^{* *}$ & $.53^{* *}$ & $\mathrm{~K}^{+}$ \\
& & & & & & 1 & $.94^{* *}$ & $\mathrm{Mg}^{2+}$ \\
& & & & & & & 1 & $\mathrm{Ca}^{2+}$ \\
\hline
\end{tabular}

different ions may have different sources. Foliar leaching, for example, is the main source of $\mathrm{K}^{+}$in throughfall, whereas the main source for $\mathrm{NH}_{4}^{+}$is dry deposition (Draaijers et al., 1997). Whelan et al. (1998) also found similarities in the spatial patterns of ions with apparently different sources. They suggested that these similarities occur because both foliar leaching and dry deposition are influenced by the density of needle biomass per area ground surface. Wet deposition is independent of the density of needle biomass per area ground surface, but as such, does not affect a positive correlation between ions for which wet deposition is an important (e.g. $\left.\mathrm{NO}_{3}^{-}\right)$or an unimportant $\left(e . g . \mathrm{SO}_{4}{ }^{2-}\right)$ source.

Negative correlations between time-average ion concentrations and throughfall water amounts (Table 4) have been reported by others (Robson et al., 1994). Both Beier et al. (1993) and Whelan et al. (1998) found an increase in the amount of throughfall water and a decrease in ion concentrations with distance from the tree stem. The increase in throughfall amount may be attributed to translocation of water in the canopy and higher interception losses close to the tree stem, where the amount of needle biomass per area is higher. The higher needle biomass also enhances particle deposition and foliar leaching close to the tree stem. This should then also result in higher ion fluxes close to the tree. No significant (negative) correlations between throughfall ion amounts and water amounts were found in this study, except for $\mathrm{NH}_{4}^{+}(r=-0.438, p=0.05$; Table 5 and Fig. 1$)$. This suggests that the observed negative correlation between water amounts and ion concentrations, except for $\mathrm{NH}_{4}^{+}$, merely reflects water interception losses.

\section{TIME-STABILITY OF SPATIAL PATTERNS OF}

\section{THROUGHFALL}

Bouten et al. (1992) showed that in Speuld the throughfall ratio of a specific funnel, defined as the amount of throughfall water collected in that funnel relative to the stand average throughfall (collection time 1 week), has a high variation for weeks with little rainfall and converges to a constant value for weeks with much rain. The funnel-specific throughfall was thus more predictable in weeks with relatively much rain. This is partly supported by the data. Figure 2A shows the ranked plots of the temporal average of the relative difference $\left(\bar{\delta}_{j}\right)$ for throughfall water amounts. The error bars indicate the considerable spread around each average. The Spearman rank correlations (Table 6A), however, show that the rankings of funnels for throughfall water amounts are significantly correlated for almost all periods. Only the rankings of periods 1 and 4 and periods 1 and 7 are not significantly correlated. Period 1 was characterised by a relatively small amount of throughfall water, giving support to the findings of Bouten et al. (1992). However, this period was significantly correlated to the remaining 6 periods. The amount of throughfall water collected by an individual funnel relative to the plot average can thus be predicted well.

Error bars and Spearman rank correlation coefficients for $\mathrm{NH}_{4}^{+}$amounts (Fig. 2B and Table 6B) show that the temporal stability of the $\mathrm{NH}_{4}^{+}$throughfall flux patterns is less than the temporal stability of the throughfall water fluxes. For $\mathrm{NO}_{3}^{-}$and $\mathrm{K}^{+}$amounts, however, except for period 1 , rankings of most periods are significantly correlated (Table 6 and Fig. 2C-D). Whelan et al. (1998) have also noted that spatial patterns of throughfall ion fluxes are less consistent than throughfall water fluxes.

\section{LINKING THROUGHFALL WATER AND FOREST FLOOR WATER CONTENTS}

Using the same TDR data, Schaap et al. (1997a) showed that there are clear spatial patterns in forest floor water contents and that these are consistent over time. The difference in water contents between wet and dry spots 
Table 6.A. Spearman rank correlations for throughfall water amounts between all periods

\begin{tabular}{|c|c|c|c|c|c|c|c|c|c|}
\hline 1 & 2 & 3 & 4 & 5 & 6 & 7 & 8 & 9 & \\
\hline \multirow[t]{9}{*}{1} & $.45^{*}$ & $.43^{*}$ & .11 & $.51 * *$ & $.45^{*}$ & .33 & $.52 * *$ & $.57 * *$ & 1 \\
\hline & 1 & $.74 * *$ & $.45^{*}$ & $.67 * *$ & $.90^{* *}$ & $.81^{* *}$ & $.56^{* *}$ & $.73^{* *}$ & 2 \\
\hline & & 1 & $.66^{* *}$ & $.72 * *$ & $.72 * *$ & $.56^{* *}$ & $.75^{* *}$ & $.78^{* *}$ & 3 \\
\hline & & & 1 & $.52 * *$ & $.64^{* *}$ & $.44^{*}$ & $.57 * *$ & $.60^{* *}$ & 4 \\
\hline & & & & 1 & $.75^{* *}$ & $.81^{* *}$ & $.82 * *$ & $.66^{* *}$ & 5 \\
\hline & & & & & 1 & $.83^{* *}$ & $.67^{* *}$ & $.73^{* *}$ & 6 \\
\hline & & & & & & 1 & $.56^{* *}$ & $.64 * *$ & 7 \\
\hline & & & & & & & 1 & $.71^{* *}$ & 8 \\
\hline & & & & & & & & 1 & 9 \\
\hline
\end{tabular}

Table 6.B. Spearman rank correlations for throughfall $\mathrm{NH}_{4}^{+}$amounts between all periods

\begin{tabular}{|c|c|c|c|c|c|c|c|c|c|}
\hline 1 & 2 & 3 & 4 & 5 & 6 & 7 & 8 & 9 & \\
\hline \multirow[t]{9}{*}{1} & .22 & .04 & -.33 & .37 & -.08 & .06 & -.20 & .01 & 1 \\
\hline & 1 & .24 & $.59 * *$ & $.79 * *$ & $.55^{* *}$ & $.79 * *$ & .08 & $.70^{* *}$ & 2 \\
\hline & & 1 & .26 & .29 & $.61^{* *}$ & -.04 & -.13 & .07 & 3 \\
\hline & & & 1 & $.51 * *$ & $.71^{* *}$ & $.55^{* *}$ & .17 & $.61^{* *}$ & 4 \\
\hline & & & & 1 & $.60^{* *}$ & $.73^{* *}$ & .20 & $.62 * *$ & 5 \\
\hline & & & & & 1 & $.41^{*}$ & .07 & .38 & 6 \\
\hline & & & & & & 1 & .11 & $.78^{* *}$ & 7 \\
\hline & & & & & & & 1 & .36 & 8 \\
\hline & & & & & & & & 1 & 9 \\
\hline
\end{tabular}

Table 6.C. Spearman rank correlations for throughfall $\mathrm{NO}_{3}{ }^{-}$amounts between all periods

\begin{tabular}{|c|c|c|c|c|c|c|c|c|c|}
\hline 1 & 2 & 3 & 4 & 5 & 6 & 7 & 8 & 9 & \\
\hline \multirow[t]{9}{*}{1} & -.09 & .07 & -.18 & .11 & -.09 & -.07 & -.21 & -.04 & 1 \\
\hline & 1 & $.44^{*}$ & $.78 * *$ & $.86^{* *}$ & $.80 * *$ & $.83^{* *}$ & $.51 * *$ & $.75^{* *}$ & 2 \\
\hline & & 1 & $.42 *$ & $.45^{*}$ & $.51^{*}$ & .08 & .24 & .26 & 3 \\
\hline & & & 1 & $.67 * *$ & $.91^{* *}$ & $.61^{* *}$ & $.55^{* *}$ & $.41^{*}$ & 4 \\
\hline & & & & 1 & $.71 * *$ & $.77^{* *}$ & $.43 *$ & $.61 * *$ & 5 \\
\hline & & & & & 1 & $.68^{* *}$ & $.50 *$ & .39 & 6 \\
\hline & & & & & & 1 & $.47 *$ & $.66^{* *}$ & 7 \\
\hline & & & & & & & 1 & $.47^{*}$ & 8 \\
\hline & & & & & & & & 1 & 9 \\
\hline
\end{tabular}

Table 6.D. Spearman rank correlations for throughfall $\mathrm{K}^{+}$amounts between all periods

\begin{tabular}{|c|c|c|c|c|c|c|c|c|c|}
\hline 1 & 2 & 3 & 4 & 5 & 6 & 7 & 8 & 9 & \\
\hline \multirow[t]{9}{*}{1} & -.28 & -.18 & -.17 & -.01 & -.15 & -.11 & -.38 & -.13 & 1 \\
\hline & 1 & $.80 * *$ & $.83 * *$ & $.82 * *$ & $.84 * *$ & $.75^{* *}$ & $.49 *$ & $.63 * *$ & 2 \\
\hline & & 1 & $.70 * *$ & $.70 * *$ & $.71 * *$ & $.63^{* *}$ & $.49^{*}$ & $.61^{* *}$ & 3 \\
\hline & & & 1 & $.78 * *$ & $.88 * *$ & $.74 * *$ & $.44^{*}$ & .38 & 4 \\
\hline & & & & 1 & $.85^{* *}$ & $.78^{* *}$ & $.45^{*}$ & $.49 *$ & 5 \\
\hline & & & & & 1 & $.92 * *$ & $.40^{*}$ & $.49^{*}$ & 6 \\
\hline & & & & & & 1 & .39 & $.51 * *$ & 7 \\
\hline & & & & & & & 1 & .36 & 8 \\
\hline & & & & & & & & 1 & 9 \\
\hline
\end{tabular}

Note: $\mathrm{n}=25, * p=0.05, * * p=0.01$ (two-tailed) 

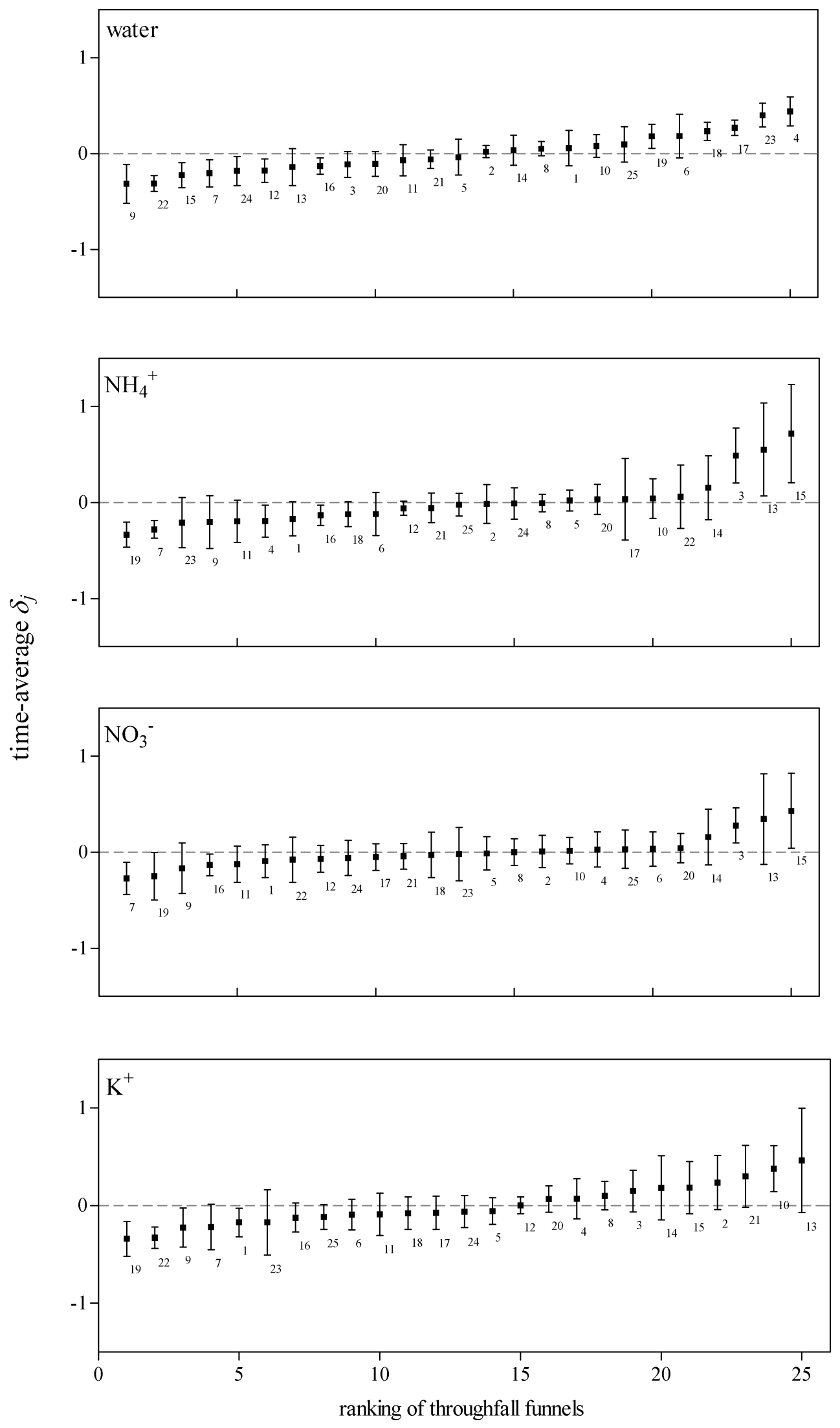

Fig. 2.A-D. Time stability plots for throughfall water, $\mathrm{NH}_{4}^{+}, \mathrm{NO}_{3}^{-}$and $\mathrm{K}^{+}$loads. Time-average $\delta_{\mathrm{j}}$ of nine periods; error bars are + and -one standard deviation; numbers refer to funnel number. See text for further details. 


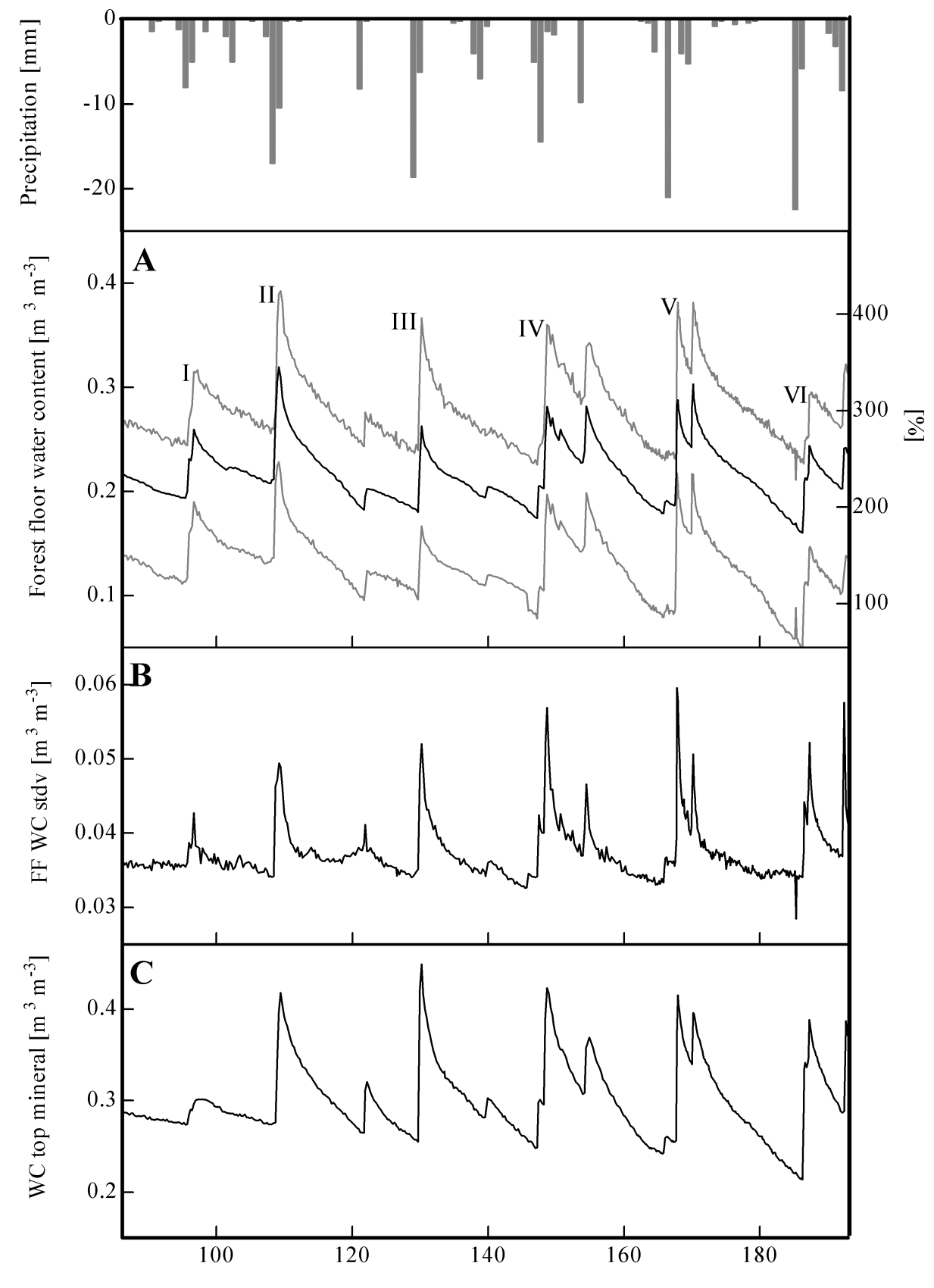

Day of year (1993)

Fig. 3.A. Time series of forest floor water content. Average of 30 sensors and wettest and driest sensor. Water contents are expressed volumetric $\left[\mathrm{m}^{3} \mathrm{~m}^{-3}\right]$ and gravimetric [\%]; water contents are corrected for sensor depth (reference depth $3.4 \mathrm{~cm}$ ); numerals refer to showers I-VI. Daily open field precipitation is shown at top of the figure.

Fig. 3.B. Time series of standard deviation of forest floor water contents (FF WC stdv).

Fig. 3.C. Time series of water contents (WC) in top mineral soil. Sensors were at $5 \mathrm{~cm}$ under top of mineral soil.

Figures are partly adapted from Schaap et al. (1997a).

amounted to $0.15 \mathrm{~m}^{3} \mathrm{~m}^{-3}$, or approximately $160 \%$ when expressed as gravimetric water content, throughout the period of measurement (April 5-July 6, 1993; Fig. 3A). The average forest floor water content in that period was 0.22 $\mathrm{m}^{3} \mathrm{~m}^{-3}$, the CV amounted to $17 \%(\mathrm{n}=30)$. These water contents were corrected for sensor depth (reference sensor depth is $3.4 \mathrm{~cm}$ ) using a correction of $0.020 \mathrm{~m}^{3} \mathrm{~m}^{-3}$ per $\mathrm{cm}$ of installed depth (Schaap et al., 1997a).

Although the temporal dynamics of the sensors are very similar (Fig. 3A), Fig. 3B shows that standard deviation of 


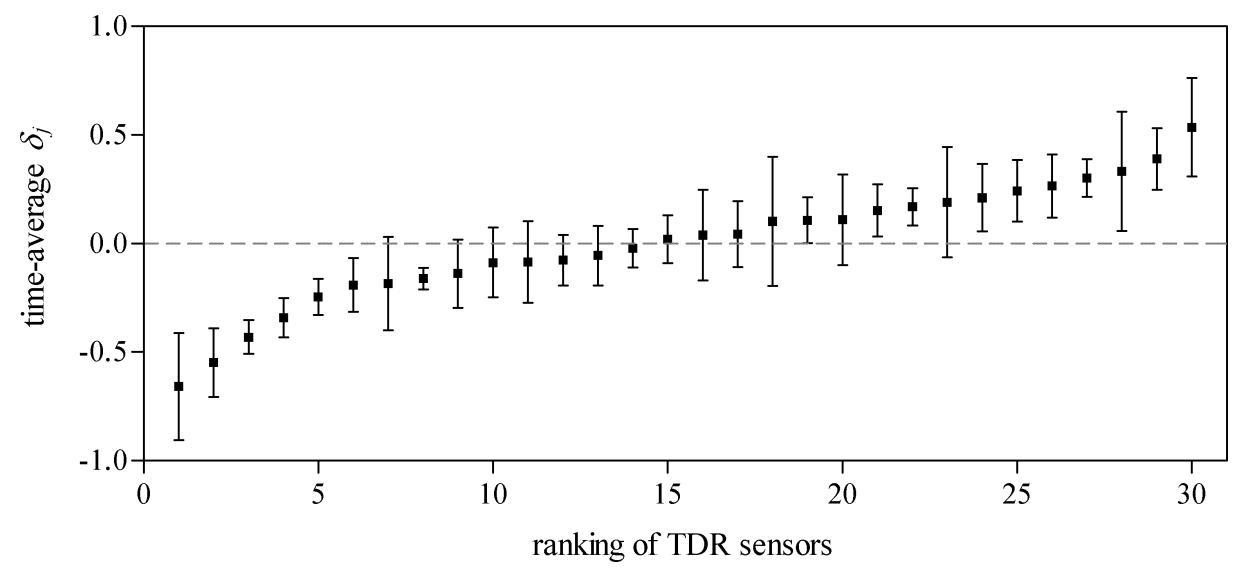

Fig. 4. Time stability plots for increase in forest floor water contents during rain showers. Time-average $\delta_{\mathrm{j}}$ of six showers; error bars are + and - one standard deviation.

the water content increases sharply on days with rain. This may be attributed to spatial variability in throughfall, drainage dynamics and/or thickness of the forest floor (Schaap et al., 1997a). The increase in forest floor water content (expressed in $\mathrm{m}^{3} \mathrm{~m}^{-3}$ ) after a rain shower was spatially variable, but observed patterns were consistent over time (Fig. 4 and Table 7). The increase was similar for sensors installed at different depths within a profile, indicating that the throughfall water was distributed evenly over the forest floor profile. There was a small, but significant correlation $(r=0.438, p=0.05)$ between the time-average water content (April 5-July 6, 1993) of a sensor and the strength of the reaction of the sensor to a rain shower. Although this indicates that wet spots react to rain more fiercely than dry spots, this does not necessarily mean that there is a direct relationship between throughfall and forest floor water spatial patterns. During showers II (April 18, 1993) and V (June 16, 1993) of the six main shower events studied in detail, 20 and $12 \mathrm{~mm}$ of throughfall were recorded (Hansen et al., 1994). The average increase

Table 7. Spearman rank correlations for increase in volumetric forest floor water content during 6 rain showers. Showers between April 5 and July 6, 1993; $\mathrm{n}=30, * * p=$ 0.01 (two-tailed).

\begin{tabular}{lllllll}
\hline I & II & III & IV & V & VI & \\
\hline 1 & $.47 * *$ & $.52^{* *}$ & $.66^{* *}$ & $.73^{* *}$ & $.73^{* *}$ & I \\
& 1 & $.68^{* *}$ & $.73^{* *}$ & $.72^{* *}$ & $.59^{* *}$ & II \\
& & 1 & $.83^{* *}$ & $.71^{* *}$ & $.72^{* *}$ & III \\
& & & 1 & $.92^{* *}$ & $.78^{* *}$ & IV \\
& & & 1 & $.74 * *$ & V \\
& & & & & 1 & VI \\
\hline
\end{tabular}

in forest floor water content after these showers was 0.11 and $0.12 \mathrm{~m}^{3} \mathrm{~m}^{-3}$, respectively. In terms of forest floor water storage, this means a storage increase of approximately 6.6 and $6.8 \mathrm{~mm}$, indicating that a large amount of the throughfall (13.4 and $5.2 \mathrm{~mm}$ ) was evaporated, taken up by plants and/ or drained to the mineral soil. Forest floor evaporation was $0.38 \mathrm{~mm} \mathrm{~d}^{-1}$ and only $2.2 \%$ of the root water uptake was derived from the forest floor (Schaap et al., 1997a). This indicates that most of the excess throughfall water drained rapidly to the mineral soil, which is supported by the similar dynamics of water contents in the top mineral soil and forest floor (Fig. 3C).

\section{IMPLICATIONS FOR N MODELLING AND N}

\section{PROCESS RESEARCH}

Spatial variability influences the performance and reliability of non-linear ecosystem models (Beier, 1998; Heuvelink and Pebesma, 1999). This also holds true for a semidistributed model like INCA (Whitehead et al., 1998), which, in essence, treats land units as perfectly homogeneous blocks. When model input is available at the point support and model output is required at the block support, which applies to almost all ecosystem models, spatial aggregation should take place after the model is run (Heuvelink and Pebesma, 1999). The throughfall data of the individual funnels provide the means to follow these instructions and, as such, to test the sensitivity of the INCA model for spatial variability. It should be noted that although spatial patterns of forest floor water content could not be related directly to throughfall water patterns, this does not mean there cannot be a strong relationship between throughfall and drainage patterns. When running a model like INCA for every individual throughfall funnel before aggregating the results, throughfall and drainage patterns will be linked directly as 
a result of the model structure. However, there may be an important feedback of root water uptake to spatial patterns in soil water, which is ignored unless it is built into the model. In the Speuld forest stand, spatial patterns of root water uptake were related to throughfall patterns around trees (Bouten et al., 1992).

Nitrification and mineralisation rates increase from dry to wet conditions (Tietema et al., 1992). When using the relationships as reported by Tietema et al. (1992) and the average water contents as reported here, dry spots $(\bar{\theta}=$ 0.13 or $\bar{w}=140 \%$ ) would, on average, nitrify approximately $55 \mathrm{mg}-\mathrm{N}$ per kg dry forest floor material per month, while nitrification in wet spots $(\bar{\theta}=0.28$ or $\bar{w}=300 \%)$ would be $150 \mathrm{mg}-\mathrm{N} \mathrm{kg}^{-1} \mathrm{month}^{-1}$. If the forest floor were of uniform thickness, nitrate production within a field plot could thus vary by a factor of 3 simply because of spatial variability in moisture content. Variations in net mineralisation within a plot would be small as net mineralisation rates are constant for gravimetric moisture contents higher than $140 \%$ (Tietema et al., 1992). The present throughfall data show that there are clear 'hotspots' and 'coldspots' of throughfall inorganic-N input to the forest floor. Differences between these spots are a factor of 2.8. This factor and the possibly large differences in nitrification rates caused by spatial variability in moisture contents, could explain a large part of the high 'spatial' $\mathrm{CV}$ for soil water $\mathrm{NH}_{4}^{+}$and $\mathrm{NO}_{3}^{-}$ concentrations reported in the literature (Manderscheid and Matzner, 1995).

During showers II and V of the six showers studied in detail, Hansen et al. (1994) recorded a total inorganic-N input by throughfall of 194 and 114 mol-N ha ${ }^{-1}$, respectively. This is approximately 6.5 and $3.8 \%$ of the yearly throughfall inorganic- $\mathrm{N}$ input. As mentioned, the average increase in forest floor water content after these showers was 0.11 and $0.12 \mathrm{~m}^{3} \mathrm{~m}^{-3}$ or 119 and $130 \%$, respectively. In the dry period after shower II, it took about eight days to return to the initial water content. Pulleman and Tietema (1999) showed that drying and rewetting of forest floor material has a profound influence on microbial transformation rates. Following these data and the data of Hansen et al. (1994), it should be noted that rewetting of the forest floor also means an addition of inorganic-N to the forest floor. As such, socalled priming effects (strong short-term changes in microbial turnover in soils; Kuzyakov et al., 2000) should not just be studied for water or nitrogen addition alone, but for both water and nitrogen addition.

\section{Conclusions}

In a Douglas fir forest, both throughfall ion and water inputs, as well as forest floor water contents, show distinct small- scale spatial patterns that are consistent with time. Throughfall ion concentrations and water fluxes are negatively correlated, but, except for $\mathrm{NH}_{4}^{+}$, no such relation could be demonstrated between throughfall ion fluxes and water fluxes. Spatial patterns in forest floor water contents are a result of patterns in forest floor thickness, drainage to the mineral soil and throughfall. As such, it is not possible to relate spatial patterns in throughfall directly to patterns in forest floor water content.

The spatial variability in nitrogen input to, and water contents of the forest floor are considerable and important for microbial transformations. The temporal dynamics of nitrogen input and water contents show that rewetting of the forest floor also means addition of inorganic- $\mathrm{N}$ to the forest floor. The results presented here have profound implications for $\mathrm{N}$ process research and for modelling of nitrogen in forest ecosystems.

\section{Acknowledgements}

Thanks is due to Judith Snepvangers for help on the timestability tests and Karin Hansen for use of her throughfall data. Gerard Heuvelink and Wim Wessel are thanked for their comments on draft versions of this article. This research was supported by the European Commission (Project EVK11999-00011). Marcel Schaap was supported by SAHRA Science and Technology Center under a grant from NSF (EAR-9876800).

\section{References}

Aber, J.D., Nadelhoffer, K.J., Steudler, P. and Melillo, J.M., 1989. Nitrogen saturation in northern forest ecosystems. Bioscience, 39, 378-386.

Beier, C., 1998. Water and element fluxes calculated in a sandy forest soil taking spatial variability into account. Forest Ecol. Manage., 101, 269-280.

Beier, C., Hansen, K. and Gundersen, P., 1993. Spatial variability of throughfall fluxes in a spruce forest. Environ.Pollut., 81, 257267.

Bouten, W., Heimovaara, T.J. and Tiktak, A., 1992. Spatial patterns of throughfall and soil-water dynamics in a Douglas-fir stand. Water Resour. Res., 28, 3227-3233.

Cosby, B.J., Ferrier, R.C., Jenkins, A., Emmett, B.A., Wright, R.F. and Tietema, A., 1997. Modelling the ecosystem effects of nitrogen deposition: Model of Ecosystem Retention and Loss of Inorganic Nitrogen (MERLIN). Hydrol. Earth Syst. Sci., 1, $137-158$

Draaijers, G.P.J., Erisman, J.W., Lövblad, G., Spranger, T. and Vel, E., 1998. Quality and uncertainty aspects of forest deposition estimation using throughfall, stemflow and precipitation measurements. TNO-MEP-Report 98/093, TNO Institute of Environmental Sciences, Energy Research and Process Innovation, Apeldoorn, The Netherlands, 73 pp. 
Draaijers, G.P.J., Erisman, J.W., Van Leeuwen, N.F.M., Römer, F.G., Te Winkel, B.H., Veltkamp, A.C., Vermeulen, A.T. and Wyers, G.P., 1997. The impact of canopy exchange on differences observed between atmospheric deposition and throughfall fluxes. Atmos. Environ., 31, 387-397.

FAO, 1988. Soil map of the world. Revised legend. World soil resources report 60 , FAO, Rome, $138 \mathrm{pp}$.

Gómez-Plaza, A., Alvarez-Rogel, J., Albaladejo, J. and Castillo, V.M., 2000. Spatial patterns and temporal stability of soil moisture across a range of scales in a semi-arid environment. Hydrol. Process., 14, 1261-1277.

Green, R.N., Trowbridge, R.L. and Klinka, K., 1993. Towards a taxonomic classification of humus forms. Forest Sci., 39, 148.

Hansen, K., Draaijers, G.P.J., Ivens, W.P.M.F., Gundersen, P. and Van Leeuwen, N.F.M., 1994. Concentration variations in rain and canopy throughfall collected sequentially during individual rain events. Atmos. Environ., 28, 3195-3205.

Harden, T. and Joergensen, R.G., 2000. Relationship between simulated spatial variability and some estimates of microbial biomass turnover. Soil Biol. Biochem., 32, 139-142.

Heimovaara, T.J. and Bouten, W., 1990. A computer-controlled 36-channel time domain reflectometry system for monitoring soil water contents. Water Resour. Res., 26, 2311-2316.

Heuvelink, G.B.M. and Pebesma, E.J., 1999. Spatial aggregation and soil process modelling. Geoderma, 89, 47-65.

Kimmins, J.P., 1973. Some statistical aspects of sampling throughfall precipitation in nutrient cycling studies in British Columbian coastal forests. Ecology, 54, 1008-1019.

Kuzyakov, Y., Friedel, J.K. and Stahr, K., 2000. Review of mechanisms and quantification of priming effects. Soil Biol. Biochem., 32, 1485-1498.

Magill, A.H., Aber, J.D., Hendricks, J.J., Bowden, R.D., Melillo, J.M. and Steudler, P.A., 1997. Biogeochemical response of forest ecosystems to simulated chronic nitrogen deposition. Ecol. Appl., 7, 402-415.

Manderscheid, B. and Matzner, E., 1995. Spatial heterogeneity of soil solution chemistry in a mature Norway spruce (Picea abies (L) Karst) stand. Water Air Soil Poll., 85, 1185-1190.

Martin, T.L., Kaushik, N.K., Trevors, J.T. and Whiteley, H.R., 1999. Review: denitrification in temperate climate riparian zones. Water Air Soil Poll., 111, 171-186.

Parkin, T.B., 1993. Spatial variability of microbial processes in soil - a review. J. Environ. Qual., 22, 409-417.

Pedersen, L.B., 1992. Throughfall chemistry of Sitka spruce stands as influenced by tree spacing. Scand. J. Forest Res., 7, 433444.

Pulleman, M. and Tietema, A., 1999. Microbial C and N transformations during drying and rewetting of coniferous forest floor material. Soil Biol. Biochem., 31, 275-285.

Robson, A.J., Neal, C., Ryland, G.P. and Harrow, M., 1994. Spatial variations in throughfall chemistry at the small plot scale. $J$. Hydrol., 158, 107-122.

Schaap, M.G., Bouten, W. and Verstraten, J.M., 1997a. Forest floor water content dynamics in a Douglas fir stand. J. Hydrol., 201, 367-383.
Schaap, M.G., de Lange, L. and Heimovaara, T.J., 1997b. TDR calibration of organic forest floor media. Soil Technol., 11, 205217.

Seiler, J. and Matzner, E., 1995. Spatial variability of throughfall chemistry and selected soil properties as influenced by stem distance in a mature Norway spruce (Picea-abies, Karst) stand. Plant Soil, 176, 139-147.

Tietema, A. and Verstraten, J.M., 1992. Nitrogen cycling in an acid forest ecosystem in the Netherlands under increased atmospheric input. The nitrogen budget and the effect of nitrogen transformations on the proton budget. Biogeochemistry, 15, 2146.

Tietema, A. and Van Dam, D., 1996. Calculating microbial carbon and nitrogen transformations in acid forest litter with N-15 enrichment and dynamic simulation modelling. Soil Biol. Biochem., 28, 953-965.

Tietema, A., Warmerdam, B., Lenting, E. and Riemer, L., 1992. Abiotic factors regulating nitrogen transformations in the organic layer of acid forest soils - Moisture and $\mathrm{pH}$. Plant Soil, 147, 69-78.

Tiktak, A. and Bouten, W., 1990. Soil hydrological system characterization of the two Aciforn stands using monitoring data and the soil hydrological model 'Swif'. Dutch Priority Program on Acidification 102.2.01, RIVM, Bilthoven, The Netherlands, $62 \mathrm{pp}$.

Tiktak, A. and Bouten, W., 1994. Soil water dynamics and longterm water balances of a Douglas fir stand in the Netherlands. J. Hydrol., 156, 265-283.

Vachaud, G., Silans, A.P.D., Balabanis, P. and Vauclin, M., 1985. Temporal stability of spatially measured soil water probability density function. Soil Sci. Soc. Amer. J., 49, 822-828.

Van Breemen, N., Burrough, P.A., Velthorst, E.J., Van Dobben, H.F., De Wit, T., De Ridder, T.B. and Reijnders, H.F.R., 1982. Soil acidification from atmospheric ammonium sulphate in forest canopy throughfall. Nature, 299, 548-550.

Van Leeuwen, N.F.M., Bleuten, W. and Hansen, K., 1994. Deposition of acidifying and basic compounds measured at the Speulder forest by means of the throughfall method. Report 9401, Department of Physical Geography, University of Utrecht, Utrecht, The Netherlands.

Vogt, K.A., Vogt, D.J., Asbjornsen, H. and Dahlgren, R.A., 1995. Roots, nutrients and their relationship to spatial patterns. Plant Soil, 168-169, 113-123.

Whelan, M.J., Sanger, L.J., Baker, M. and Anderson, J.M., 1998. Spatial patterns of throughfall and mineral ion deposition in a lowland Norway spruce (Picea abies) plantation at the plot scale. Atmos. Environ., 32, 3493-3501.

Whitehead, P.G., Wilson, E.J. and Butterfield, D., 1998. A semidistributed Integrated Nitrogen model for source assessment in Catchments (INCA): Part I - model structure and process equations. Sci. Total Environ., 210/211, 547-558.

Wright, R.F., Roelofs, J.G.M., Bredemeier, M., Blanck, K., Boxman, A.W., Emmett, B.A., Gundersen, P., Hultberg, H., Kjonaas, O.J., Moldan, F., Tietema, A., Van Breemen, N. and Van Dijk, H.F.G., 1995. NITREX: Responses of coniferous forest ecosystems to experimentally changed deposition of nitrogen. Forest Ecol. Manage., 71, 163-169. 